\title{
少量アスピリンの抗血小板療法について 一血小板凝集能からの検討一
}

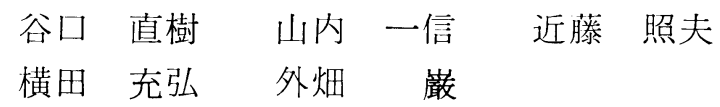

\begin{abstract}
＜要 約> aspirin は抗血小板薬として従来より各種血栓症の治療に使用されている. 近年 aspirin の大量投 与は prostacyclin 合成を阻害し，血栓生成化作用すると指摘され，その投与量が再検討されつつある。本研究 の目的は aspirin の種々の単回扣よび連日投与にお梳る血小板凝集能抑制効果を検討することより，その至適 投与量を決定することである。対象は虚血性心疾患，并膜症抢よび大動脈炎症候群などの心疾患患者71名であ り，健常人13名を対照とした。 aspirin 1 日80，160，330，660および $990 \mathrm{mg}$ 連日投与群における $4 \mu \mathrm{M}$ ADP 最大凝集率には有意差は認められず，いずれの群の凝集率も aspirin 投与を受けていない健常群のそれに比し て低值を示した。 aspirin $160 \mathrm{mg}$ 以上の単回投与では投与後 1 時閒以内に凝集能抑制効果が出現した。単回投 与の凝集能抑制効果持続日数の 平均值は $330 \mathrm{mg}$ 投与では 4 日， $660 \mathrm{mg}$ では 5.5 日，1320 $\mathrm{mg}$ では 6 日であっ た， aspirin による胃腸障害，出血等の副作用の出現頻度は dose dependent であることを考虑すると，本薬を 長く投与する必要がある場合, 可及的少量が望ましい.ADP 凝集抑制効果の観点からは 1 日量 $80 \mathrm{mg}$ の連日 投与または160mg の隔日投与が至適投与法と考兄られた。
\end{abstract}

Key words: 血小板凝集能, 少量アスピリン

\section{緒言}

抗血小板薬の 1 つであるアスピリンは, 血小板凝集能 抑制効果により血栓形成を抑制するが，大量投与ではプ ロスタサイクリン生成をも抑制し ${ }^{1)}$ ，かえって血栓形成 促進的に作用するとされ ${ }^{2}$ ， アスピリンの至適投与量が 再検討されつつある. 今回, 我々はアスピリンを各種循 環器疾患患者に種々の用量用法で投与し, その血小板凝 集能抑制効果より至適投与量を検討した.

\section{方 法}

対象は 健常人 13 名 (26 38歳, 平均年齢31.2歳), 心 房細動患者 9 名 (31 70歳, 平均年䶨55.6歳), 狭心症 患者18名（40～68歳，平均年歯51.5歳），心筋梗塞症患 者26名（43～77歳, 平均年柃58.2歳），大動脈炎症候群 患者 6 名（19～55歳，平均年歯32.4歳），僧帽弁狭窄症 患者 6 名（29～62歳，平均年齢40.8歳）および他の心疾

N. Taniguchi, K. Yamauchi, T. Kondo, M. Yokota,

I. Sotobata 名古屋大学医学部第一内科 受付日1981。7。6
患患者 6 名である，血栓塞栓症急性期の患者は本研究の 対象から除外した（表 1 ）.

血小板凝集能測定 のための 採血は，20G の注射針を 連結したポリスチンン注射器を用い，血管および皮下組 織の損傷を最小限に抑えるょう細心の注意を払い, 肘静 脈より $9 \mathrm{~m} l$ 採取した。血液検体をあらかじめ冷却した $3.8 \%$ クェン酸ナトリウム $1 \mathrm{~m} l$ を入れたポリスチレン チューブに直ちに入れ，静かに混和した。

採取した血液検体に800回転, 10分間の遠心操作を加 之, 多血小板血浆（PRP）を作製し，更に3,000回転， 20分間の遠心操作にて乏血小板血浆 (PPP) を作製し

表 1 対象

\begin{tabular}{|c|c|c|}
\hline 内 訳 & 数（女性） & 年令（平均） \\
\hline 者 & $13(2)$ & $26-38(31.2)$ \\
\hline 心 房＼cjkstart細＼cjkstart動 & $9(2)$ & $31 \sim 70(55.6)$ \\
\hline 狭心 & $18(4)$ & $40 \sim 68(51.5)$ \\
\hline 心筋梗塞 症 & $26(0)$ & $43 \sim 77(58.2)$ \\
\hline 大動脈炎症候群 & $6(6)$ & $19 \sim 55(32.4)$ \\
\hline 僧帽弁狭窄症 & $6(6)$ & $29 \sim 62(40.8)$ \\
\hline の & $6(4)$ & $55 \sim 68(62.3)$ \\
\hline
\end{tabular}


た. 血小板凝集計 (Bio/Data 社製 Platelet Aggregation Profiler-2A 型) を用い, PRP に凝集惹起物質を加えて 擋拌し，凝集によって生ずる透過光の増大を記録した。 凝集惹起物質として $4 \mu \mathrm{M} \mathrm{ADP}, 2 \mu \mathrm{g}$ コラゲンおよび $1 \mu \mathrm{M}$ エピネフリンを用い，凝集曲線より最大凝集率を 求めた.

各種心疾患患者にアスピリン $80,160 ， 330 ， 660$ また は $990 \mathrm{mg}$ のいずれかを 4 週間以上連日投与し， $4 \mu \mathrm{M}$ ADP による最大凝集率を求めた. またアスピリン投与 を受けていない心疾患患者に80，160，330または660mg のいずれかのアスピリン単回投与を行ない，投与後 1 時 間および 2 時間の $4 \mu \mathrm{M}$ ADP 最大凝集率 とアスピリン 血浆濃度を求めた。更に 330,660 または $1,320 \mathrm{mg}$ のい ずれかのアスピリン単回投与を行ない, 投与後 1 時間, 2 時間， $1 \sim 9$ 日の $2 \mu \mathrm{g}$ コラゲンおよび $1 \mu \mathrm{M}$ エピネ フリンによる最大凝集率を求めた.

\section{成 續}

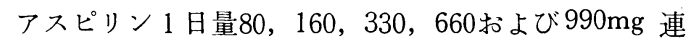
日投与群に拈ける $4 \mu \mathrm{M}$ ADP による最大凝集率の平均 值 (土標準偏差) はそれぞれ56.9(土7.0)\%, 56.1（土 12.7）\%, 49.7 ( $\pm 18.8 ） \%, 51.5$ ( $\pm 11.2 ） \%$ おび 54.2 (土14.3）\%であり各群間に有意差を示さず, アス ピリン無投与健常群の58.8（士27.7）\%に比して低い傾 向を示した（図 1).

アスピリン $80 \mathrm{mg}$ 単回投与における $4 \mu \mathrm{M} \mathrm{ADP}$ 最大 凝集率の平均值 は投与前73.8（土17.5）\%, 投与後60 分57.2（土14.7）\%，投与後 120 分65.0（土13.0）\%で あり, 投与前後に有意な凝集率の変化は認められなか った. しかしながら 160mg 単回投与のそれは87.1（士

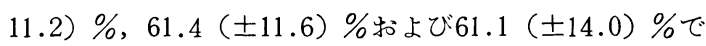
あり，投与後60分および120分值は投与前值に比して有 意に低下した $(\mathrm{p}<0.005)$ （図 2$) .330 \mathrm{mg}$ 単回投与で は投与前79.1土（11.7）\%，投与後 60分65.9（土13.1） \%および投与後120分62.2（土14.9）\%であり，投与後 60 分および120分梿は投与前值に比して有意に低下した $(\mathrm{p}<0.005)$ （図 3 ).660mg 単回投与では73.4（土 $10.0) \% ， 61.8( \pm 12.8 \%$ および63.8（土11.4）\% であり，160および $330 \mathrm{mg}$ 投与と同様に，投与後 60 分 および120分值は投与前值に比して有意に低下した（ $\mathrm{p}<$ 0.025).

アスピリン $80,160 ， 330 お よ ひ ~ 660 \mathrm{mg}$ 単回投与にお けるアスピリン平均血浆濃度は投与後60分ではそれぞれ

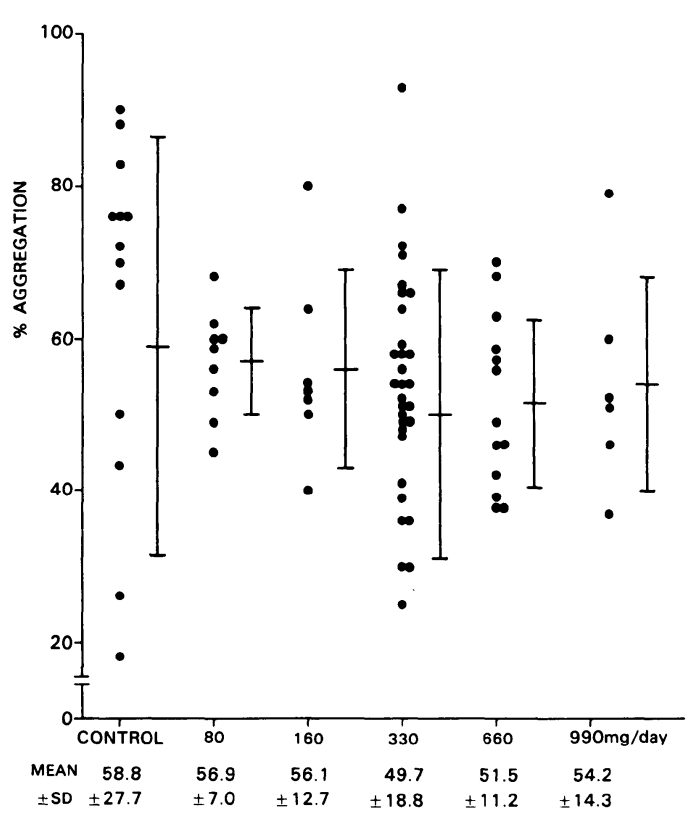

図 1 アスピリン連日投与群における4 による血小板最大凝集率

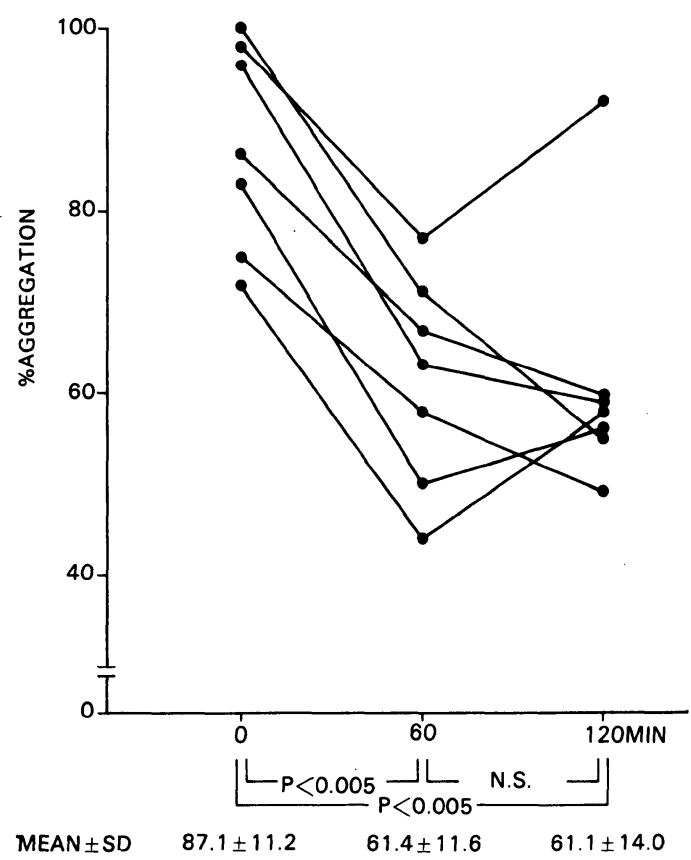

図 2 アスピリン $160 \mathrm{mg}$ 単回投与における $4 \mu \mathrm{M}$ $\mathrm{ADP}$ による血小板最大凝集率の変動 


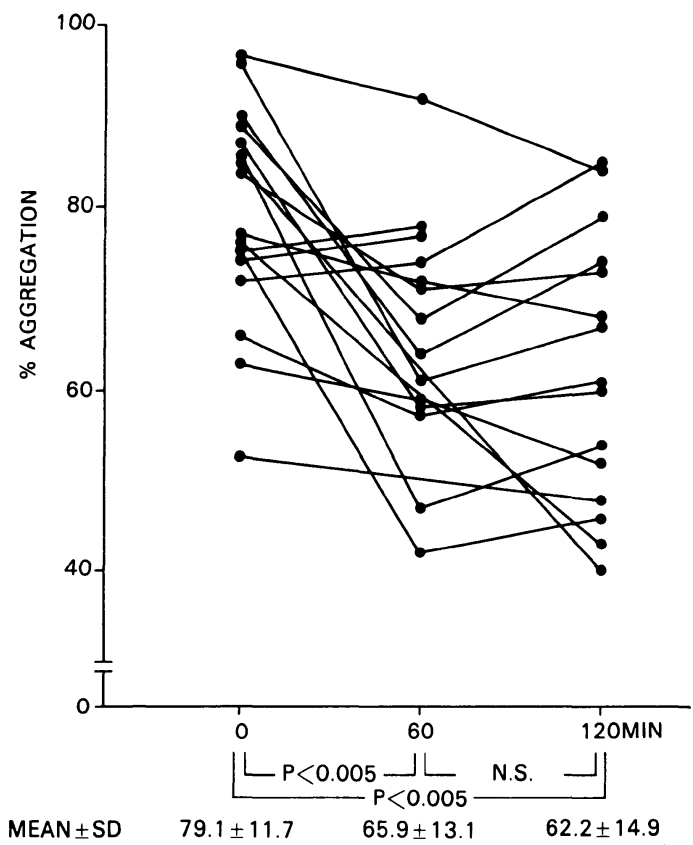

図 3 アスピリン $330 \mathrm{mg}$ 単回投与における $4 \mu \mathrm{M}$ $\mathrm{ADP}$ による血小板最大凝集率の変動

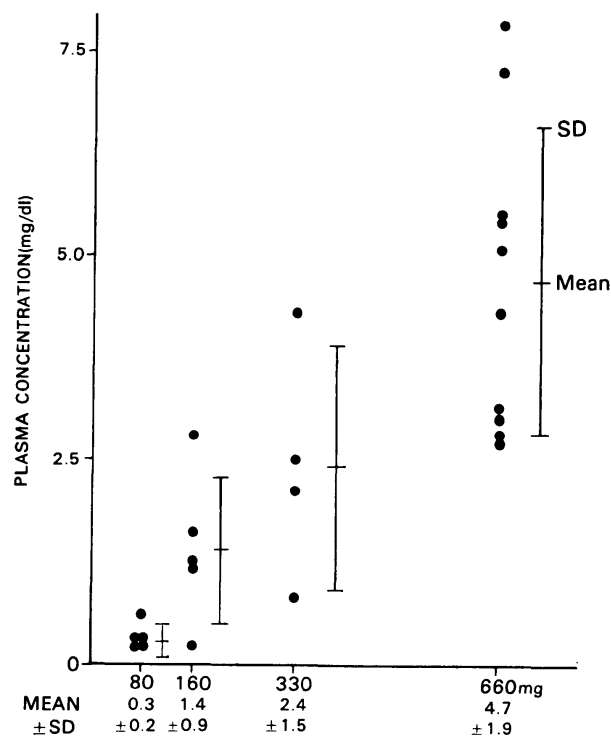

図 4 アスピリン単回投与 60 分後の血墏濃度

$0.3( \pm 0.2), 1.4( \pm 0.9), 2.4$ (土1.5) および4.7（士 1.9 ) $\mathrm{mg} / \mathrm{d} l$ (図 4)，投与後120分ではそれぞれ 0.4 (士 0.2)，1.6（士0.8），2.9（士2.0）および5.2（士1.4） $\mathrm{mg} / \mathrm{d} l$ であり, 投与量の増加と共に血浆濃度は増加した

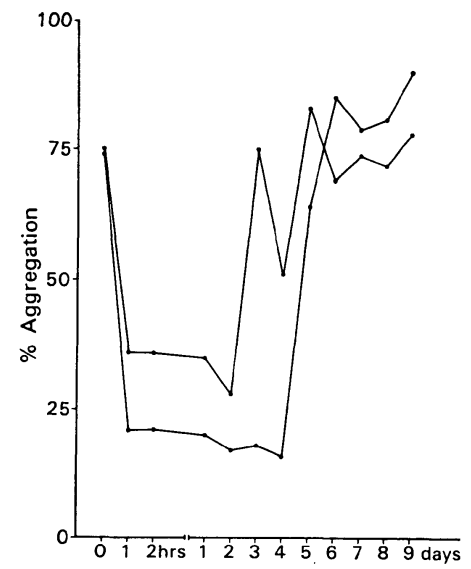

図 5 アスピリン $330 \mathrm{mg}$ 単回投与におけるェピネ フリン最大凝集率の経日的変動

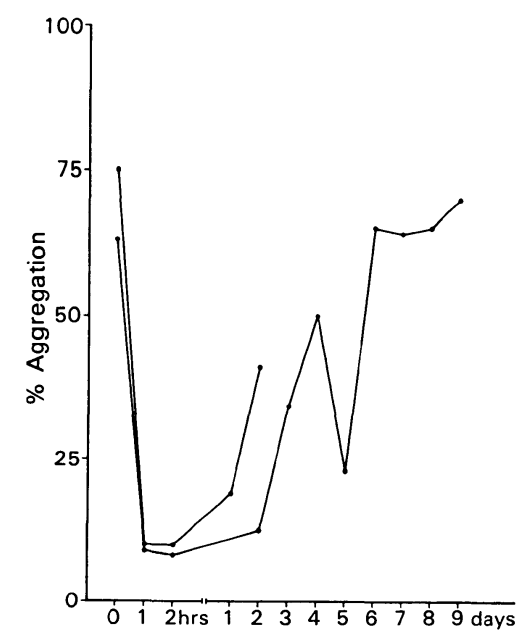

図6アスピリン $330 \mathrm{mg}$ 単回投与におけミコラゲ ン最大凝集率の経日的変動

が，24時間後ではいずれの投与量でも血浆中にアスピリ ンは検出されなかった.

アスピリン単回投与に打ける凝集抑制効果持続日数 （投与前最大凝集率の $75 \%$ 以上に 回復する 日数）を $2 \mu \mathrm{g}$ コラゲンおよび $1 \mu \mathrm{M}$ エピネフリンを用い求めた. 1,320 $\mathrm{mg}$ 単回投与における効果持続日数の平均値は 6 日であ り，660mg のそれは5.5日，および330mg のそれは 4 日 であった（図 5 , 図6).

\section{考察}

最近, 各種循環器疾患, 特に虚血性心疾患, 大動脈炎 
症候群，僧帽弁狭窄症に打いて血小板凝集能の六進して いる症例が多いことが報告されて括り ${ }^{34)}$ ，これらの疾 患では活性化された血小板機能を抑制するためにアスピ リンを投与することが多い。

アスピリンは血小板内アラキドン酸代謝経路のサイク ロオキシゲナーゼを非可逆的に阻害することにより ${ }^{5}$, 血小板凝集および血管収縮作用を有するトロンボキサン $\mathrm{A}_{2}{ }^{6}$ の合成を低下させ，血小板機能を抑制する。しかし ながらアスピリン投与量が大であると, 同時に血管内皮 細胞のサイクロオキシゲナーゼも阻害し，血小板凝集抑 制拉よび血管払張作用を有するプロスタサイクリンクの 合成を低下させる ${ }^{1)}$ ，故にアスピリンは大量投与ではむ しろ血栓生成促進作用を有すると危惧され2), その至適 投与量が再検討されつつある.

Masotti らは25名の健常人でアスピリン単回投与にお ける血小板凝集抑制率およびプロスタサイクリン産生抑 制率の経時的变化を検討した，彼らは血小板凝集抑制効 果およびプロスタサイクリン産生抑制効果がほぼ最大に 達するとされる単回投与後 2 時間において ADP，コラゲ ンおよびェピネフリンによる血小板凝集率を $50 \%$ 抑制す るアスピリン単回投与量はそれぞれ $3.4 \mathrm{mg} / \mathrm{kg}, 3.2 \mathrm{mg} / \mathrm{kg}$ および $3.2 \mathrm{mg} / \mathrm{kg}$ であり，これ対してプロスタサイク リン産生を $50 \%$ 抑制する量は $4.9 \mathrm{mg} / \mathrm{kg}$ であると報告し た. $5 \mathrm{mg} / \mathrm{kg}$ 程度の少量アスピリン単回投与では, プロ スタサイクリン産生抑制効果持続時間はほぼ24時間であ り，これに対して凝集抑制効果は $2 \sim 3$ 日持続するとい $5^{8)}$.

前川99 は各種血栓症10例を対象としてアスピリン 300 ～1,500mg 単回投与後のコラゲン血小板凝集率の 変化 を検討した．投与後 1 時間以内にコラゲン凝集抑制が認 められたが，その程度は各投与量間で有意差がなかっ た.アスピリンを $300 \mathrm{mg} 2$ 日打き投与, $750 \mathrm{mg}$ 連日投 与，1,500mg 2 日招き投与した場合，いずれの群にも 凝集抑制効果が認められた。 $300 \mathrm{mg}$ を 1 〜 2 日打きに 投与すれば多くの症例でコラゲン凝集を充分抑制できる が，時に $750 \mathrm{mg}$ 連日投与しても抑制が不十分な症例の あることを報告した．小林ら ${ }^{10)} も$ 多くの血栓症患者で， アスピリン $330 \mathrm{mg}$ の 2 日おき投与により十分なコラゲ ン凝集抑制を観察した。

以上の報告より, 血栓塞栓症予防のためには血小板凝 集能を充分抑制し，プロスタサイクリン合成阻害を最少 限とする用量用法でアスピリンを投与すべきである.

本研究に打いてはアスピリン 1 日量 80 〜990mg を連
日投与した 各群間で血小板凝集率に有意差が認められ ず，いずれの群の血小板凝集率も健常群のそれよりも低 值で, 1 日量 $80 \mathrm{mg}$ といら極めて少量でも十分血小板凝 集能が抑制されらることが示された。このような少量に 扣いてプロスタサイクリン合成阻害は極めて少ないと考 号れる. 抗血小板薬としてのアスピリン投与量は従来 $1 \mathrm{~g}$ 前後といわれていたが，この量では胃腸症状などの 副作用が発現しやすい。この研究で示されたように1日 量 $80 \mathrm{mg}$ の少量投与で充分な血小板凝集抑制効果が得ら れれば臨床使用に極めて好都合と考兄られる. しかし 330 990mg の連日投与によって血小板凝集能が充分抑 制されえない症例が存在することにも留意すべきであ る.これらの症例では血小板凝集能を頻回に測定し，ア スピリン投与量の増量または逆に減量, あるいは他の抗 血小板薬との併用をも考慮すべきである.

アスピリンの血小板凝集能抑制効果は不可逆的で，血 小板寿命と密接に関係するとされる。我々の研究におい て $330 \mathrm{mg}$ 単回投与による 血小板凝集抑制効果は 4 日間 以上持続したことより隔日または 2 日おきに, 更には週 2 回の投与でも十分血小板凝集能を抑制しらると思われ る.

単回投与に抢ける凝集抑制効果発現は $160 \mathrm{mg}$ 以上で は経口投与後 1 時間以内であった. 前川らによれば 300 $\mathrm{mg}$ 以上の経口投与では 1 時間以内に効果が発現したと いう。これらのことょり，不安定狭心症等のように早急 に抗血小板療法を必要とする場合には，初日に $160 \mathrm{mg}$ を，翌日からは毎日 $80 \mathrm{mg}$ のアスピリンを投与する方法 も考えられる.

アスピリン血浆濃度はアスピリン経口投与後 1 時間以 内に急速に上昇したが，血浆濃度と血小板凝集抑制率と は相関しなかった．血浆中のアスピリンが血小板内に取 り込まれて効果が発現することを考虑すれば，血小板内 アスピリン濃度あるいはサイクロオキシゲナーゼ活性と の相関の検討が必要であろう.

本研究では，アスピリンの投与法および投与量を in vitro にお汁る 血小板凝集抑制の 観点から検討した。 1 日量 $80 \sim 160 \mathrm{mg}$ の少量アスピリンの維持量が適正であ るかどうかは，今後アスピリン投与例にお汁る心筋梗塞 の初回または再発作, 心房細動や弁膜症の血栓塞栓症の 発症がアスピリン非投与群に比較して少ないかどうかを 追跡調查することにより明らかにされると考えられる. 


\section{結語}

アスピリンの種々の用量用法における血小板凝集能抑 制効果よりその至適投与量を検討した.

1）アスピリン $80 \sim 160 \mathrm{mg} /$ 日の連日投与により有意 な血小板凝集能抑制効果が得られた.

2）アスピリン $160 \mathrm{mg}$ 以上の単回投与では 60 分以内 に凝集能抑制効果が出現した. その効果は $330 \mathrm{mg}$ 投与 では約 4 日間持続した。

3） in vitroにおける血小板凝集能抑制効果よりみ て，アスピリン維持投与量は通常，80 $\mathrm{mg} /$ 日連日，また は160mg/日隔日が適当と考えられた。

\section{文献}

1) Baenziger, N.L. et al.: Cultured human skin fibroblasts and arterial cell produce a labile platelet-inhibitory prostaglandins. Biochem. Biophys. Res. Commun., 78: 294, 1977.

2) Kelton, J.G. et al.: Thrombogenic effect of high-dose aspirin in rabbits. J. Clin. Invest., 62: 892, 1978.

3) 谷口直樹, 山内一信 : 虚血性心疾患に打ける血 小板凝集能の検討, 第52回日本循環器学会東海 地方会にて発表, 岐阜, 1980-7.

4) O'Brien, J.R. et al.: The quantitation of platelet aggregation induced by four compounds: A study in relation to myocardial infarction. Thrombosis et Diathesis Haemorrhagica., 16: 752, 1966.

5) Weiss, H.J. et al.: Prostaglandin $\mathrm{E}_{2}$ potentiation of platelet aggregation induced by Lass endoperoxide, Absent in storage pool disease: Normal after aspirin ingestion. Brit. J. Haematol., 32: 257, 1976.

6) Hamberg, M. et al.: Thromboxanes: A new group of biologically active compounds derived from prostaglandin endoperoxides. Proc. Natl. Acad. Sci., 72: 2994, 1975.

7) Moncada, S. et al.: An enzyme isolated from arteries transforms prostaglandin endoperoxides to an unstable substance that inhibits platelet aggregation. Nature, 263: 663, 1976.

8) Masotti, G. et al.: Differential inhibition of prostacyclin production and platelet aggregation by aspirin. Lancet, 8: 1213, 1979.

9) 前川 正：心筋硬塞予防としてのアスピリン療 法. 最新医学, $\mathbf{3 3}:$ 1379, 1978.

10) 小林紀夫：アスピリンとアスピリン様薬剤. 最 新医学, 35:2216, 1980 . 
Abstract

\title{
Studies on Antiplatelet Therapy of Low Dosage of Aspirin from the View Point of Its Effect on Platelet Aggregation
}

\author{
Naoki Taniguchi, Kazunobu Yamauchi, Teruo Kondo, Mitsuhiro Yokota and \\ Iwao Sotobata
}

Aspirin has been widely used as a potent antithrombotic drug in clinical practice. However, the optimal dosage for the prevention of thrombo-embolic events is still controversial because high-dose aspirin inhibits $\mathrm{PGI}_{2}$ production in vessel walls as well as $\mathrm{TXB}_{2}$ production in platelets. This study was designed to investigate the optimal clinical aspirin dosage from the view point of its effects on ADP-induced platelet aggregation.

The materials were composed of 13 normal subjects (control group) and 71 patients with cardiovascular diseases. Various daily doses of aspirin (80, 160, 330, 660 and $990 \mathrm{mg}$ ) were given to patients (aspirin group) for more than 4 weeks, and percent ADP aggregation was studied.

There was no significant difference in percent aggr-

First Department of Internal Medicine, Nagoya University School of Medicine egation between any two of the aspirin-treated groups, all of which showed a tendency to have lowered percent aggregation as compared with the control group. A single dose of $160 \mathrm{mg}$ of aspirin inhibited ADP plctelet aggregation within one hour after oral ingestion. The inhibitory effect of aspirin on collagen- and epinephrine-induced aggregation persisted for 4 days when $330 \mathrm{mg}$ of aspirin was given and for 5.5 days when $660 \mathrm{mg}$ was adminstered. No significant correlation was observed between plasma concentration of aspirin and its effects on platelet aggregation.

The present study showed that a daily dose of as small as $80 \mathrm{mg}$ of aspirin was sufficient to inhibit platelet aggregation. However, further clinical trials should be made to ascertain that this low daily dosage of aspirin will effectively prevent future thrombo-embolic events.

Key words: Platelet aggregation, low dosage of aspirin 